\title{
Quantitative estimates of tropical temperature change in lowland Central America during the
} last 42 ka

Anna-Lena Graue $1^{1 *}$, David A. Hodell ${ }^{1}$, Stefano M. Bernasconi ${ }^{2}$

${ }^{1}$ Godwin Laboratory for Palaeoclimate Research, Department of Earth Sciences, University of Cambridge, UK

${ }^{2}$ Geological Institute, ETH Zurich, Zurich, $\mathrm{CH}$

*corresponding author: e-mail: grauelanna@gmail.com

\begin{abstract}
Determining the magnitude of tropical temperature change during the last glacial period is a fundamental problem in paleoclimate research. Large discrepancies exist in estimates of tropical cooling inferred from marine and terrestrial archives. Here we present a reconstruction of temperature for the last $42 \mathrm{ka}$ from a lake sediment core from Lake Petén Itzá, Guatemala, located at $17^{\circ} \mathrm{N}$ in lowland Central America. We compared three independent methods of glacial temperature reconstruction: pollen-based temperature estimates, tandem measurements of $\delta^{18} \mathrm{O}$ in biogenic carbonate and gypsum hydration water, and clumped isotope thermometry. Pollen provides a nearcontinuous record of temperature change for most of the glacial period but the occurrence of a noanalog pollen assemblage during cold, dry stadials renders temperature estimates unreliable for these intervals. In contrast, the gypsum hydration and clumped isotope methods are limited mainly to the stadial periods when gypsum and biogenic carbonate co-occur. The combination of palynological and geochemical methods leads to a continuous record of tropical temperature change in lowland Central America over the last $42 \mathrm{ka}$. Furthermore, the gypsum hydration water method and clumped isotope thermometry provide independent estimates of not only temperature, but also the $\delta^{18} \mathrm{O}$ of lake water that is dependent on the hydrologic balance between evaporation and precipitation over the lake surface and its catchment. The results show that average glacial temperature was cooler in lowland Central America by $5-10{ }^{\circ} \mathrm{C}$ relative to the Holocene. The coldest and driest times occurred during North Atlantic stadial events, particularly Heinrich stadials (HSs), when temperature decreased by up to 6 to $10{ }^{\circ} \mathrm{C}$ relative to today. This magnitude of cooling is much greater than estimates derived from Caribbean marine records and model simulations.
\end{abstract}

The extreme dry and cold conditions during HSs in the lowland Central America were associated with fresh water forcing in the North Atlantic, which led to reduced Atlantic Meridional Overturning Circulation, cooling of the North Atlantic, southern advance of sea-ice, and southward shift of the Intertropical Convergence Zone. Although some models correctly predict the sign of temperature and 
precipitation changes, they consistently underestimate the degree of observed cooling and decreased precipitation over land in lowland Central America.

\section{Keywords:}

Neotropics, paleoclimatology, Heinrich stadials, lake sediments, clumped isotope thermometry, gypsum hydration water

\section{Introduction}

The tropics are important for controlling the global energy heat budget and water vapor content in the atmosphere, and are the dominant source of interannual climate variability today. However, the role of this region in past climate change on glacial-to-interglacial and millennial time scales is not well known (e.g., Clement and Peterson, 2008). Foremost is the question of the magnitude of temperature change in the tropics during the last glacial period, which has been debated by the scientific community since the 1980s (Rind and Peteet, 1985; Colinvaux et al., 1996). In the northern Neotropics, for example, large discrepancies exist in estimates of tropical cooling that are inferred from marine $\left(\sim 2{ }^{\circ} \mathrm{C}\right)$ and terrestrial $\left(\sim 6^{\circ} \mathrm{C}\right)$ archives (Rind and Peteet, 1985; Colinvaux et al., 1996). To date only a few records exist and are based mainly on indirect temperature estimates derived from pollen and snowline depression (Leyden et al., 1994; Bush et al., 2009 and references therein; Roy and Lachniet, 2010; Correa-Metrio et al., 2012).

Here we present a new reconstruction of temperature and precipitation changes over the last $42 \mathrm{ka}$ from a lake sediment core from Lake Petén Itzá, northern Guatemala, located at $17^{\circ} \mathrm{N}$ in lowland Central America. Previous studies of sediment cores from Lake Petén Itzá showed that alternating layers of clay- and gypsum-rich sediment reflect times of wetter and drier conditions, respectively (Hodell et al., 2008). The glacial period was cooler and drier than the Holocene with the most arid conditions coinciding with Greenland stadials, especially those associated with Heinrich events. Pollen assemblages were dominated by xeric-tolerant taxa and the $\delta^{18} \mathrm{O}$ values of ostracods were highest, indicating cold arid conditions (Hodell et al., 2008; Escobar et al., 2012; Correa-Metrio et al., 2012). In contrast, interstadials and the Last Glacial Maximum (LGM) contain pollen indicative of temperate pine-oak forest, indicating cool humid conditions (Bush et al., 2009; Correa-Metrio et al., 2012). The proxies from Lake Petén Itzá show a similar variability as observed in Greenland and sediments from the Cariaco Basin (Peterson et al., 2000), suggesting a consistent regional response to millennial-scale climate changes (Hodell et al., 2008).

To estimate the magnitude of temperature change during the last glacial period, Hodell et al. (2012) used tandem measurements of $\delta^{18} \mathrm{O}$ in biogenic carbonate and gypsum hydration water to determine the $\delta^{18} \mathrm{O}$ and $\delta \mathrm{D}$ of lake water and its temperature. The results suggested that temperatures were 6 to $10{ }^{\circ} \mathrm{C}$ colder than mean annual temperature in the region today during HS1. This cooling is far greater 
than observed in nearby marine sediment cores and in model simulations. To test the low temperatures derived by the gypsum hydration method, we applied clumped isotope thermometry as an independent tool to obtain both temperature and $\delta^{18} \mathrm{O}$ of water from carbonate minerals. The derived temperatures are also compared with pollen-based temperature estimates using the Modern Analog Technique (MAT) (Correa-Metrio et al., 2012). The combination of all three methods provides a continuous record of tropical temperature change in lowland Central America over the last 42 ka.

\section{Study site}

We used a sediment core from Lake Petén Itzá, the largest and deepest lake in the Central Petén Lake district in northern Guatemala $\left(16.55^{\circ} \mathrm{N}, 89.50 \mathrm{~W}\right)$ (Fig. 1). Epilimnetic temperatures reach $\sim 30{ }^{\circ} \mathrm{C}$ during summer with a well-developed thermocline at about 30m water depth, which persists through most of the year (Hillesheim et al., 2005; Pérez et al., 2010) (Fig. 2). The average hypolimnetic temperature is set by winter mixing and is on average $\sim 25{ }^{\circ} \mathrm{C}$. Today, the lake water has a high $\mathrm{pH}$ $(\sim 8)$ and a low total ionic concentration that is dominated by calcium, magnesium, sulphate, and bicarbonate ions. The modern lake water is saturated for calcium carbonate but under-saturated for gypsum (Hodell et al., 2006).

The mean oxygen and hydrogen isotopic composition of lake water today is $\sim 2.7 \%$ and $15.2 \%$, respectively, and surface water is slightly more enriched during summer because of evaporation from the lake surface (Hodell et al., 2012) (Fig. 2).

The majority of precipitation falls during summer months (May-October) and is on average $1600 \mathrm{~mm}$ per year. In winter, the precipitation is low but polar air masses occasionally bring light winter rains (nortes) with cold fronts. The mean annual air temperature is $26{ }^{\circ} \mathrm{C}$, with mean monthly air temperatures reaching as low as $19{ }^{\circ} \mathrm{C}$ during winter and as high as $31^{\circ} \mathrm{C}$ during summer.

\section{Material and Methods}

Core PI-6 $\left(17.00162^{\circ} \mathrm{N}, 89.476844^{\circ} \mathrm{W}\right.$, water depth $\left.71 \mathrm{~m}\right)$ was collected during the Petén Itzá Scientific Drilling Project in 2006 (Hodell et al., 2006). The lithostratigraphy and radiocarbon chronology of PI-6 have been described previously (Hodell et al., 2008; Mueller et al., 2010; Escobar et al., 2012). For ostracod $\delta^{18} \mathrm{O}$, we use the previously published results of Escobar et al. (2012). For the pollen-based temperature estimates, we used data published by Correa-Metrio et al. (2012) that is based on the MAT.

3.1 Gypsum hydration water method 
The oxygen and hydrogen signature of the water from which the mineral is formed can be determined by measuring the gypsum hydration water if: (i) isotopic equilibrium is achieved between the mother and the hydration water; (ii) The fractionation factors during gypsum formation are known and temperature-independent; (iii) No isotopic exchange has occurred between environmental and hydration water after gypsum deposition (Hodell et al., 2012). Gypsum is believed to have formed authigenically in the littoral zone of Lake Petén Itzá where the evaporation rate was higher than that in deeper water (Hillesheim et al., 2005). Today, the difference between the $\delta^{18} \mathrm{O}$ of the epilimnion and hypolimnion varies between $0 \%$ during winter mixes to $0.3 \%$ during summer stratification. However, the lake level dropped by $56 \mathrm{~m}$ relative to today during the last glacial (Hodell et al. 2008). Considering that core PI- 6 was taken from $71 \mathrm{~m}$, the water depth would have been $15 \mathrm{~m}$, which means that the water at the site would have been well mixed (mixing depth today is $20 \mathrm{~m}$ ). Hodell et al. (2012) showed that the corrected oxygen and hydrogen isotope values from the gypsum hydration waters from Lake Petén Itzá differed substantially from sediment pore water and fall on the regional evaporative water line, which suggests that isotopic exchange has not occurred between the hydration water and interstitial water. The fractionation factor $\left(\alpha=1.004 \pm 0.0002\right.$ for $\delta^{18} \mathrm{O}, \alpha=0.98$ for $\left.\delta \mathrm{D}\right)$ between mother and hydration water has been determined by Gonfiantini and Fontes (1963) and Fontes and Gonfiatini (1967) and replicated by Hodell et al. (2012). Furthermore, the authors found no significant temperature dependence in the range between $12{ }^{\circ} \mathrm{C}$ and $37{ }^{\circ} \mathrm{C}$. An error of \pm 0.0002 in the fractionation factor corresponds to an error of $\pm 0.2 \%$ in $\delta^{18} \mathrm{O}_{\text {water }}$ and $\pm 1{ }^{\circ} \mathrm{C}$ in temperature, respectively (Hodell et al., 2012).

We measured the $\delta^{18} \mathrm{O}$ and $\delta \mathrm{D}$ of hydration water using 300-400 mg of gypsum. Gypsum crystals were picked from the $>350 \mu \mathrm{m}$ size fraction under a microscope and pulverized. The extraction method for gypsum hydration water followed Hodell et al. (2012) except that we used the newly developed Water Analyzer Sample Preparation (WASP) device in the Godwin Laboratory which allows up to six samples to be extracted simultaneously (Gazguez et al., 2015), as opposed to the single sample method of Hodell et al. (2012). Gypsum samples were placed in a vacuum extraction line (pressure $10^{-3} \mathrm{mbar}$ ) and pumped for 3 hours to remove absorbed water. Crystallization water from the gypsum was slowly released by step heating the sample to $400{ }^{\circ} \mathrm{C}$ (under vacuum) using a temperature programmable oven. The released hydration water was trapped in glass break seal tubes using liquid nitrogen for at least $45 \mathrm{~min}$ before flame sealing. A standard (Cambridge New Gypsum or "NewGyp") was run with each set of five samples. Samples were weighed before and after heating to calculate weight loss, which should be $20.9 \%$ for pure gypsum.

Water isotopes were analyzed with a Picarro L2140-i cavity ringdown laser spectrometer and an A0211 high precision vaporizer. Each sample was analyzed ten times by injection of $2 \mu 1$ of water into the vaporizer. The first three analyses were disregarded to avoid memory effects and the remaining 
seven averaged to give an in-run precision of $\pm 0.04 \%$ and $\pm 0.17 \%$ for $\delta^{18} \mathrm{O}$ and $\delta \mathrm{D}$, respectively $(1 \sigma)$.

Hodell et al. (2012) used a Picarro L1102-i cavity ringdown laser spectrometer and an A0211 high precision vaporizer. With the Picarro L2140-i cavity ringdown laser spectrometer and an A0211 high precision vaporizer we could increase the in-run precision from $\pm 0.1 \%$ to $\pm 0.04 \%$ for $\delta^{18} \mathrm{O}$, and from $\pm 1 \%$ to $\pm 0.17 \%$ for $\delta \mathrm{D}$ (1-standard deviation), respectively.

The results were calibrated using international standards VSMOW, GISP and VSLAP. In addition, an enriched water standard $\left(\delta^{18} \mathrm{O}=10.93 \%\right.$ and $\delta \mathrm{D}=38.80 \%$ VSMOW $)$ was also analyzed in each run. To correct for drift an internal lab standard was measured after each set of three samples. The external error was estimated by repeated analyses of the gypsum lab standard (NewGyp), which resulted in a mean and standard deviation of $0.28 \pm 0.2 \%$ for $\delta^{18} \mathrm{O}$ and $-51.21 \pm 1.4 \%$ for $\delta \mathrm{D}(\mathrm{n}=17)$. This compares with an external precision of $\pm 0.1 \%$ for $\delta^{18} \mathrm{O}$ and $\pm 1.4 \%$ for $\delta$ D reported by Hodell et al. (2012). All results are reported relative to VSMOW. All $\delta^{18} \mathrm{O}$ and $\delta \mathrm{D}$ values are given in the supplement Table S1.

\subsection{Clumped Isotope Analyses}

Clumped isotope thermometry uses the excess abundance of measured ${ }^{13} \mathrm{C}-{ }^{18} \mathrm{O}$ bonds in carbonates relative to its expected stochastic abundance: $\Delta_{47}=\left(\frac{R^{47}}{R^{47}}-1\right) \times 1000$, where $\mathrm{R}^{47}$ is the measured abundance ratio of mass- 47 relative to mass- 44 ; and $\mathrm{R}^{47^{*}}$ is the expected abundance ratio relative to mass-44, if the isotopes in the sample were stochastically distributed among all possible isotopologues (Eiler and Schauble, 2004; Wang et al., 2004b; Ghosh et al., 2006; Schauble et al., 2006; Eiler, 2007).

To investigate whether the shells calcify in equilibrium, bulk samples of the two most abundant gastropod species (Tryonia exigua and Cochliopina sp.) were analyzed from core top samples along a N-S transect across the lake (Mueller et al., 2010). The same gastropod species were used downcore for paleotemperature estimation at Site PI-6. These gill-breathing, thick-shell hydrobid species precipitate aragonite in near-isotopic equilibrium with lake water and are widely distributed in eastern Mexico and Central America (Covich, 1976; Dunning et al., 1998; Shanahan et al., 2005). In Lake Petén Itzá both species are very common as subfossils but due to the low abundance of the species today no detailed ecological study of both species exists (Covich, 1976; Shanahan et al., 2005).

The samples were prepared according to the protocol described by Grauel et al. (2013) that includes several pre-cleaning steps before analysis. The measurements were performed using a ThermoScientific MAT253 mass spectrometer modified to simultaneously measure masses 44 through 49 at the Godwin Laboratory, University of Cambridge. For acidification of carbonate, we used a similar approach as ETH Zurich that is based on repeated measurements (8-10) of 150-180 $\mu \mathrm{g}$ 
aliquots of calcium carbonate using a ThermoScientific Kiel device modified by the addition of a PoraPak trap to purify the $\mathrm{CO}_{2}$ (Schmid and Bernasconi, 2010; Schmid et al., 2012). The purified $\mathrm{CO}_{2}$ gas was measured against a reference gas formed by acidification of Carrara marble $\left(\delta^{13} \mathrm{C}_{\mathrm{VPDB}}=1.957\right.$ $\%$ and $\delta^{18} \mathrm{O}_{\mathrm{VPDB}}=6.569 \%$ ), since its isotopic composition is close to the biogenic carbonate samples that are usually measured in the Godwin Laboratory. To correct for non-linearity and scrambling effects in the source, we used $\mathrm{CO}_{2}$ gases of different isotopic composition heated to $1000{ }^{\circ} \mathrm{C}$ to ensure a stochastic distribution (Huntington et al., 2009). Furthermore, water-equilibrated $\mathrm{CO}_{2}$ gases were measured and all results are reported relative to the Absolute Reference Frame (ARF; Dennis et al., 2011; see Supplementary for details). To monitor the scale compression and correct for isotope effects caused by the source of the mass spectrometer, we measured carbonate standards that span a wide range in $\Delta_{47}$ along with each set of samples (Schmid and Bernasconi, 2010). The routine measurement of carbonate standards of different isotopic composition is necessary when using a Kiel IV preparation device because the gas flows through a separate capillary into the mass spectrometer, and thus the heated gas calibration does not fully correct for possible effects caused by the preparation device (Grauel et al., 2013). We used five different carbonate standards that cover a wide range of bulk isotopic compositions (Table 1 ). The accepted $\Delta_{47}$-values of the standards used for the correction are: Iso-A $=0.267 \%$; Iso-B $=0.248 \%$; Iso-R $=0.501 \%$; Iso-C $=0.723 \%$; internal Carrara marble $($ Carrara $\mathrm{Z})=0.379 \%$ (Table 1$)$. The four standards Iso-A, Iso-B, Iso-R and Iso-C are also used at ETH Zurich for correction (Meckler et al., 2014), Table 1. To calibrate our five carbonate standards, we measured them together with the heated and water-equilibrated gases over a time period of four weeks.

At least eight aliquots of two different standards were included in each run of 36 to 44 single measurements. Initially, each analysis included 6 cycles of alternating reference and sample gas measurements of $26 \mathrm{sec}$ integration with $10 \mathrm{sec}$ idle time after a change over valve switch (Schmid et al., 2012). The $m / z 44$ beam intensities decrease from $\sim 17 \mathrm{~V}$ to $14 \mathrm{~V}$ with an average standard error of the mean of $\pm 0.011 \%$ on $\Delta_{47}$ for 10 aliquots of $\sim 160 \mu \mathrm{g}$. To achieve a higher precision we adjusted the focus settings of the mass spectrometer and increased the number of cycles per analysis to 10 cycles of alternating reference and sample gas measurements of $26 \mathrm{sec}$ integration with $10 \mathrm{sec}$ idle time following change over valve switching. With this setting, the initial $\mathrm{m} / \mathrm{z} 44$ beam intensities was $20 \mathrm{~V}$ and decreased to $14 \mathrm{~V}$ with an average standard error of the mean of $\pm 0.009 \%$ on $\Delta_{47}$ for 10 aliquots of $\sim 160 \mu \mathrm{g}$.

We corrected all data to the ARF and for acid fractionation (correction factor $0.0637 \%$; Henkes et al., 2013) before adjusting the results using the calibrated values of our five carbonate standards in the manner proposed by Meckler et al. (2014), i.e., with a moving average encompassing 11 standards measurements. The average adjustments range between 0.007 and $0.011 \%$ for measurements carried out using 6 cycles, and between 0 and $0.007 \%$ when using 10 cycles per analysis. Runs where the carbonate standards show an offset of more than $0.03 \%$ were repeated if possible - otherwise, the 
corrections were performed using the offsets from the individual run, instead of the mean offsets over 11 standards measurements. Overall, only two runs showed an offset of the carbonate standards of more than $0.03 \%$; we repeated the sample measurements for both samples.

The $\Delta_{47}$-temperatures were calculated according to the calibration by Kele et al. (2015) with the derived calibration equation: $\Delta_{47}=\left(0.044 \pm 0.005 \times 10^{6}\right) / \mathrm{T}^{2}+(0.205 \pm 0.05047)$, where $\Delta_{47}$ is in per mil and $\mathrm{T}$ is the temperature in Kelvin. The $\Delta_{47}$-temperature calibration is based on calcitic and aragonitic travertines, tufa and cave deposits from natural springs and wells, and spans a temperature range between $6{ }^{\circ} \mathrm{C}$ and $95^{\circ} \mathrm{C}$ (Kele et al., 2015). Furthermore, Kele et al. (2015) measured three biogenic samples that fit very well with the calibration line (Kele et al., 2015). To compare results between the two laboratories (Godwin Laboratory and ETH Zurich) we measured two of the three reported biogenic samples used in the Kele et al. (2015) calibration (Table 1) in addition to the four carbonate standards. The values show an average difference of $0.011 \%$ between the two laboratories. We used this value to correct our results to ETH Zurich before applying the calibration equation. This small difference between the two laboratories is possibly caused by different approaches in the correction scheme as ETH Zurich uses the newly developed pressure baseline (PBL) correction (Bernasconi et al., 2013) that has not yet been established at the Godwin Laboratory. The slope of the Kele et al. (2015) calibration is slightly lower than the recently published slope of $0.0526 \pm 0.0025$ of Zaarur et al. (2013; reaction temperature: $25^{\circ} \mathrm{C}$ ) and steeper than calibrations of other laboratories where the reaction temperature was $90{ }^{\circ} \mathrm{C}$ (e.g., Dennis and Schrag, 2010). This indicates that offsets among laboratories may be related to the different acid reaction temperatures (Fernandez et al., 2014). The use of the Kele et al. (2015) calibration results in good agreement with modern water temperatures ( $\mathrm{T}$ $\left.=30-25{ }^{\circ} \mathrm{C}\right)$ and $\delta^{18} \mathrm{O}\left(\delta^{18} \mathrm{O}_{\mathrm{w}}=2.7 \%\right.$ of Lake Péten Itzá: $\mathrm{T}=28.4 \pm 1.2{ }^{\circ} \mathrm{C}$ and $\delta^{18} \mathrm{O}_{\mathrm{w}}=2.7 \pm 0.2 \%$, than the calibration by Zarrur et al. (2013): $\mathrm{T}=31 \pm 1.2{ }^{\circ} \mathrm{C}$ and $\delta^{18} \mathrm{O}_{\mathrm{w}}=3.3 \pm 0.2 \%$, and the calibration by Dennis and Schrag (2010): $\mathrm{T}=33.1 \pm 1.2{ }^{\circ} \mathrm{C}$ and $\delta^{18} \mathrm{O}_{\mathrm{w}}=3.7 \pm 0.2 \%$.

As the temperature sensitivity of the clumped isotope method is $0.0045 \% /{ }^{\circ} \mathrm{C}$ (Ghosh et al., 2006) an external precision of this order is necessary to achieve a precise temperature signal. To achieve greater precision we measured duplicates or triplicates of the PI-6 samples when possible. Because the variability is still high for the last glacial samples we used an average of 2 to 10 samples for this time interval. The $\delta^{18} \mathrm{O}$ of the lake water was determined with the aragonite-water temperature equation of Grossman and $\mathrm{Ku}(1986)$. All $\triangle_{47}$-values are reported in the supplementary Table S2.

\section{Results}

\subsection{Gypsum hydration water}

We analyzed a total of 69 samples for gypsum hydration water from PI-6 spanning the time interval from $\sim 10.7$ to $\sim 41.7 \mathrm{ka}$ and three samples from piston core PI-8-IV-02-STIIA ( 10.4 ka; Hillesheim 
et al., 2005). All samples that were reported by Hodell et al. (2012) were re-measured to have an internally consistent data set. In total we re-measured 27 samples from PI-06 spanning the time interval from $\sim 10.7 \mathrm{ka}$ to $\sim 18.5 \mathrm{ka}$ and three samples from piston core PI-8-IV-02-STIIA ( 10.4 ka; Hillesheim et al., 2005).

The calculated $\delta^{18} \mathrm{O}$ and $\delta \mathrm{D}$ of the lake water range from 4.5 to $6.9 \%$ and 22.8 to $36.1 \%$, respectively, when corrected for isotopic fractionation between mother and hydration water (Fig. 3B, C). All glacial values are considerably higher than the mean $\delta^{18} \mathrm{O}$ and $\delta \mathrm{D}$ of the lake water today $(\sim 2.7$ $\%$ and $15.2 \%$, respectively) and in situ pore water (Hodell et al., 2012).

The average $\delta^{18} \mathrm{O}(5.6 \pm 0.5 \%)$ indicates relatively dry conditions during all Heinrich Stadials (HSs) (Fig. 3B). During HS4 ( 37.5 ka) the $\delta^{18} \mathrm{O}$ values range between 4.8 and $6.5 \%$, whereas during HS3 $(\sim 31 \mathrm{ka})$ and HS2 $(\sim 24 \mathrm{ka})$ the $\delta^{18} \mathrm{O}$ values increase up to $6.9 \%$. During $\mathrm{HS} 1$, the $\delta^{18} \mathrm{O}$ values vary between 5.1 and $6.4 \%$ with maximum values at $\sim 15.5 \mathrm{ka}$. Sediments deposited during the BollingAllerod are dominated by clay and the gypsum hydration water method was not possible for this interval. At the end of the Bolling-Allerod, $\delta^{18} \mathrm{O}$ values increased to $\sim 5.6 \%$ during the Younger Dryas and Preboreal Period (13 to $10.5 \mathrm{ka}$ ). The lowest values of $4.5 \%$ are observed at the start of the Holocene at $\sim 10.4 \mathrm{ka}$.

A similar trend as those displayed by $\delta^{18} \mathrm{O}$ can be observed for the $\delta \mathrm{D}$ values that range between 22.8 and $36.1 \%$ during HSs (Fig. 3C, Table 2). During HS1 the highest $\delta$ D values of $\sim 31.4 \%$ are observed. The $\delta \mathrm{D}$ values are on average slightly lower during the Younger Dryas and the Preboreal Period, averaging $29 \%$. The lowest values of $23.6 \%$ occur at the start of the Holocene at $\sim 10.4 \mathrm{ka}$.

4.2 Paleotemperature estimates using gypsum hydration water and biogenic carbonate

We applied the method of Hodell et al. (2012) to calculate paleotemperatures using co-occurring gypsum hydration water and biogenic carbonate. For the oxygen isotope of biogenic carbonate we used the benthic ostracod Limnocythere opesta (Escobar et al., 2012), and the gastropods Cochliopina sp. and Tryonia exigua (Fig. 3A). The oxygen isotopes of gastropods were determined using a Kiel IV device coupled to a MAT253 mass spectrometer. The analytical error was estimated by repeated measurements of Carrara marble and was better than $\pm 0.08 \%$ for $\delta^{18} \mathrm{O}(1 \sigma)$. All results are reported relative to VPDB. Paleotemperatures were calculated using the calcite-water equation of Anderson and Arthur (1983) for ostracod calcite and the aragonite-water equation of Grossmann and Ku (1986) was used for the gastropod shells, where the $\delta^{18} \mathrm{O}$ water was derived from the gypsum hydration water.

The temperatures of the lake water varied from 24 to $13{ }^{\circ} \mathrm{C}$ during the last glacial, which is significantly lower than the mean annual temperature of the lake today, which averages $\sim 25{ }^{\circ} \mathrm{C}$ (Fig. 3A). During HS4, HS3 and HS2, temperatures averaged $\sim 19 \pm 2{ }^{\circ} \mathrm{C}$, when using the ostracod L. opesta, 
which is $6{ }^{\circ} \mathrm{C}$ cooler than today (Fig. 2A, Table 2). In comparison, average temperatures during HS1 averaged $\sim 17 \pm 2{ }^{\circ} \mathrm{C}$, which is $8{ }^{\circ} \mathrm{C}$ cooler than today. During the Younger Dryas and the Preboreal periods, temperatures were $\sim 20 \pm 2{ }^{\circ} \mathrm{C}$.

The estimated temperatures are slightly greater using gastropod aragonite and indicate lake temperatures between 25 and $13{ }^{\circ} \mathrm{C}$ during the last glacial (Fig. 3A). During HS4 and HS2 the average temperatures reflect slightly warmer conditions $\left(\sim 22 \pm 0.5{ }^{\circ} \mathrm{C}\right)$ compared to the ostracodderived temperatures. During HS3 the average temperature of the lake water is $19 \pm 2{ }^{\circ} \mathrm{C}$. Similar to the ostracods, the gastropods indicate the coldest conditions during HS1 with an average temperature of $\sim 18 \pm 3{ }^{\circ} \mathrm{C}$ (Fig. 3, Tab.2).

\subsection{Clumped isotope temperatures}

The $\Delta_{47}$-temperature values of gastropods from the core top samples $\left(\sim 28 \pm 1{ }^{\circ} \mathrm{C}\right)$ are within the modern range of epilimnetic temperatures $\left(25-30{ }^{\circ} \mathrm{C}\right)$ in Lake Petén Itzá (Fig. 2, 3A). Similarly, the calculated $\delta^{18} \mathrm{O}$ of the lake water of $\sim 2.7 \%$ from the clumped isotope measurement is close to surface values during summer (Fig. 2, 3B). These core-top results suggest gastropods calcify in isotopic equilibrium and should provide reliable paleotemperature estimates.

The results of PI-6 show that the $\Delta_{47}$-temperatures significantly decreased from modern values of $\sim 28$ ${ }^{\circ} \mathrm{C}$ to an average glacial value of $\sim 19 \pm 1{ }^{\circ} \mathrm{C}$ (Fig. 3A). During HS4, HS3 and HS2, the $4_{47^{-}}$ temperatures are on average $19{ }^{\circ} \mathrm{C}$ which is between the temperatures obtained from the gypsum hydration method using ostracod and gastropod shells $\left(18.6{ }^{\circ} \mathrm{C}\right.$ and $21{ }^{\circ} \mathrm{C}$, respectively, Table 2). During HS1, the $\Delta_{47}$-temperatures are on average $17 \pm 2{ }^{\circ} \mathrm{C}$ which is in agreement with the values obtained from the gypsum hydration method (Fig. 3A). Both geochemical methods support the assumption of considerably cooler climate conditions during the last glacial compared to the Holocene (Fig. 4a).

With the $\Delta_{47}$-temperatures and the measured $\delta^{18} \mathrm{O}$ carbonate, it is possible to calculate the $\delta^{18} \mathrm{O}$ of the host water. The $\delta^{18} \mathrm{O}_{\mathrm{w}}$ of the glacial lake water ranges between 4.8 and $6.4 \%$, which is within the same range as the results obtained from gypsum hydration water (Fig. 3B and 4b).

\section{Discussion}

By combining the three proxies (gypsum hydration water, clumped isotopes, and pollen) it is possible to construct a continuous record of tropical temperature change in lowland Central America for the last $42 \mathrm{ka}$. In addition, comparison of temperatures and $\delta^{18} \mathrm{O}_{\mathrm{w}}$ derived by the gypsum hydration method and clumped isotope thermometry provides a test of the methodology, and hence is a powerful tool for testing paleotemperature estimates. In the following discussion we first evaluate the 
results of these three temperature methods with respect to other tropical temperature estimates. Next, we discuss the paleoclimate significance of the results, and compare them to model simulations.

\subsection{Paleotemperature proxies}

The various paleotemperature proxies track different aspects of the seasonal and annual temperature cycle. Pollen reflects mean annual air temperatures but the MAT is not reliable for those times characterized by a no-analog pollen assemblage, such as during Heinrich stadials. The clumped isotope temperatures rely on gastropods because $>2 \mathrm{mg}$ of carbonate is required for the analysis. Gastropods live in the littoral zone of Lake Petén Itzá and are found in surface sediment samples from the shoreline to a water depth of $23 \mathrm{~m}$ (Mueller et al., 2010). Thus, clumped isotope temperatures on gastropods reflect epilimnetic temperatures. In contrast, ostracods are bottom dwellers and record hypolimnetic temperatures that are set during winter mixing.

In general, we expect temperatures to be warmer for gastropods than benthic ostracods because they live in the surface mixed layer where temperature today can exceed $30^{\circ} \mathrm{C}$ in summer.

The three temperature proxies record different parts of the annual cycle: pollen estimates reflect mean annual air temperature, the $\Delta_{47}$-temperatures of gastropods reflect epilimnetic conditions biased towards the warm season, and gypsum hydration temperatures using ostracod shells reflect hypolimnetic temperatures biased towards winter, and epilimnetic temperatures when using gastropod shells.

The pollen-based MAT provides a continuous record over the past $42 \mathrm{ka}$ but underestimates the cooling during Heinrich stadials because of a no-analogue pollen assemblage. In contrast, the clumped isotopes and gypsum hydration method are largely limited to the Heinrich stadials when gypsum and carbonate microfossils co-occur in the sediment. Thus, the combination of the palynological and geochemical proxies from the interstadial (clay) and stadial (gypsum) periods, respectively, provide a continuous history of temperature change.

\subsection{Paleotemperature estimates}

The pollen-based MAT indicates a mean annual air temperature of $\sim 20^{\circ} \mathrm{C}$ for the last glacial period, which is $5{ }^{\circ} \mathrm{C}$ cooler than present. During the LGM and interstadials, the pollen consists of pine-oak forest with estimated temperatures of 3-5 ${ }^{\circ} \mathrm{C}$ less than the Holocene (Correa-Metrio et al., 2012). The coldest conditions during the last glacial period did not occur during the LGM, but rather during the Heinrich stadials. During these periods, pollen assemblages consist of drought-associated taxa (e.g., Acacia and Poaceae) and total pollen concentrations are very low suggesting a sparsely vegetated savannah-like environment with no modern analog in the region today (Correa-Metrio et al., 2012). 
Although the pollen-derived MAT indicate cooler temperatures during the Heinrich stadials (Fig. 3A), they underestimate the cooling because of a no-analogue pollen assemblage.

The temperatures derived using ostracod shells suggest significantly lower $\left(\sim 18{ }^{\circ} \mathrm{C}\right)$ water temperatures than today $\left(\sim 25^{\circ} \mathrm{C}\right)$ during the last glacial period. The coldest temperatures are recorded during HS1 $\left(\sim 17^{\circ} \mathrm{C}\right)$, while the other HSs are slightly warmer, averaging $\sim 19^{\circ} \mathrm{C}$. The same pattern is observed using gastropods but the temperatures are uniformly warmer reflecting epilimnetic temperatures during the warm season (Table 2).

The average glacial $\Delta_{47}$-temperatures are in the same range $\sim 19{ }^{\circ} \mathrm{C}$ as observed for the temperatures derived by the gypsum hydration method (Tab. 2), considering the uncertainty in $\Delta_{47}$-temperatures is $\pm 2{ }^{\circ} \mathrm{C}$ (Fig. 3A, 4a). The magnitude between the gastropod- and the ostracod derived temperatures is smaller during the last glacial $\left(\sim 1-2{ }^{\circ} \mathrm{C}\right)$ compared to the Holocene $\left(\sim 4-5{ }^{\circ} \mathrm{C}\right)$. The reason might be that the lake level was lowered during glacial times $(\sim 56 \mathrm{~m}$ lower relative to today; Hodell et al., 2008), and thus the lake is better mixed throughout the entire year compared to today when the lake is stratified during the summer.

The coldest temperatures are recorded during HS1 (Fig. 3A). Both the gypsum hydration temperatures and the $\Delta_{47}$-temperatures indicate a severe cooling during $\mathrm{HS} 1$ of $6-10{ }^{\circ} \mathrm{C}$ that is not replicated by the pollen-based temperature estimates, which are only $3-6^{\circ} \mathrm{C}$ cooler because of the no-analogue pollen assemblage (Fig. 3A). Similar to the hydration water method, $\Delta_{47}$-temperatures are $1-2{ }^{\circ} \mathrm{C}$ warmer during the other HSs compared to HS1.

\subsection{Comparison with marine records}

The comparison of glacial temperatures from Lake Petén Itzá to nearby marine temperature records from the Gulf of Mexico and the Cariaco Basin shows that the magnitude of temperature change on land was much greater than the ocean surface. The trends of the pollen-based MAT record in Petén Itzá resemble the record from the Caribbean and Gulf of Mexico during the LGM and interstadials (Fig. 5), but the pollen-based temperatures are $\sim 4{ }^{\circ} \mathrm{C}$ colder than the marine records. In contrast, the severe cooling of 6 to $10{ }^{\circ} \mathrm{C}$ indicated by the geochemical proxies during HSs is not reflected in nearby marine cores from the Caribbean (e.g., Lea et al., 2003; Schmidt et al., 2004) (Fig. 5). For example, $\mathrm{Mg} / \mathrm{Ca}$-based SST from the Cariaco Basin does not indicate markedly cooler temperatures during HS1 compared to the LGM (Lea et al., 2003) (Fig. 5). The most prominent deglacial event in the Cariaco record was the Younger Dryas when SSTs dropped by 3 to $4{ }^{\circ} \mathrm{C}$ (Lea et al., 2003). In the Gulf of Mexico, $\mathrm{Mg} / \mathrm{Ca}$-temperatures from the Orca Basin show the lowest SST $\left(\sim 24{ }^{\circ} \mathrm{C}\right)$ during the first half of HS1 (Williams et al., 2010), while no pronounced cooling is observed during the other HSs (Fig. 5). 
The differences between the terrestrial and $\mathrm{Mg} / \mathrm{Ca}$-based marine temperature estimates may be related, in part, to a salinity effect on the $\mathrm{Mg} / \mathrm{Ca}$ ratio of foraminifera (Arbuszewski et al., 2010). During glacial times the salinity was higher in the Caribbean (Schmidt et al., 2004), which could lead to an underestimation of the magnitude of glacial temperatures (Hodell et al., 2012). However, the magnitude of the salinity correction is too small to account for all of the discrepancy between our record and Caribbean SST. In addition, small-scale temperature changes are more buffered in the marine environment compared to Lake Petén Itzá when the lake level was reduced during HSs causing a possible greater temperature change compared to today.

\subsection{Isotopic composition of paleolake water}

The higher $\delta^{18} \mathrm{O}$ and $\delta \mathrm{D}$ of lake water during the last glacial period relative to lake water today indicates drier conditions (Fig. 3). In particular, HS1 had the greatest $\delta^{18} \mathrm{O}$ and $\delta \mathrm{D}$ values marking the most arid conditions of the last $42 \mathrm{ka}$. To describe the deviation from the global meteoric water line, we calculated the deuterium-excess ( $d$-excess; Craig, 1961). The $d$-excess is predominately controlled by kinetic effects, and lower values indicate evaporation of lake water under conditions of lower relative humidity and temperature. In Lake Petén Itzá, the $d$-excess values are on average considerably lower during the last glacial ( -16) compared to modern values of -6 (Fig. 3D). This supports the severe dry conditions indicated by the high $\delta^{18} \mathrm{O}$ and $\delta \mathrm{D}$ values during HSs and the xeric pollen assemblage (Correa-Metrio et al., 2012).

The severe dry conditions, especially during HS1, are consistent with precipitation changes inferred from Cariaco Basin sediments (e.g., Peterson et al., 2000; Deplazes et al., 2013). In contrast, speleothem growth patterns in northeastern Brazil indicate more humid conditions during HS1 and HS4 (Wang et al., 2004a). This inverse correlation between rainfall in northern and southern Neotropics suggests a southward shift of the ITCZ during HSs that had a large effect on the tropical hydrological cycle (Clement and Peterson, 2008). Previous studies have linked these rapid climate events in the tropics to millennial-scale oscillations of temperature in Greenland (Peterson et al., 2000). Our results suggest that the tropical response to freshwater forcing, and hence the weakening of AMOC (e.g., Menviel et al., 2014), was greater during HS1 than during other HSs. Furthermore, the extremely dry conditions during HS1 coincide with one of the most extreme drought events of the last $50 \mathrm{ka}$ in Africa (Stager et al., 2011). However, it is not clear whether the drought was associated with a severe cooling in Africa as observed in the lowland Neotropics.

\subsection{Comparisons with model simulations}

Model studies suggest that a reduction in Atlantic thermohaline circulation causes intense cooling in the North Atlantic and reduced precipitation in the Northern Hemisphere tropics (Chiang, 2009). The 
model study by Chiang and Friedman (2012) identify a cold tongue of water extending southwesterly from the eastern north Atlantic into the tropical Atlantic during times of AMOC weakening, causing a southward migration of the ITCZ and arid conditions in the northern hemisphere tropics. The very cold north Atlantic conditions during these events are documented in the alkenone SST record from the Iberian Margin (Bard et al., 2000; Martrat et al., 2007, 2014). Figure 6 illustrates the one-to-one correlation between cold, arid events in Petén Itzá and cold events on the Iberian Margin. The latter occur mainly during Heinrich stadials when sea ice expanded far to the south and the Polar Front reached the Iberian Margin.

Although the broad features of model results suggest drier conditions in the Neotropics (e.g., Chiang et al., 2009), they do not capture the magnitude of temperature depression inferred from our geochemical proxies. Modern coupled GCMs that include vegetation and cloud cover also fail to explain the large land-sea discrepancy in the tropics during HSs (Seager et al., 2000; Schneider von Deimling et al., 2006). Climatological studies have suggested that variations in rainfall are nonlinearly related to SSTs (Folkins and Braun, 2003). A temperature drop of $2{ }^{\circ} \mathrm{C}$ in SSTs could cause a large reduction in convective activity and hence precipitation (Folkins and Braun, 2003), thereby causing a larger land-sea discrepancy. Lake Petén Itzá is located close to the boundary between the convective tropics and the subtropics, and Hodell et al. (2012) suggested the potential importance of a convective threshold in this region.

In summary, our study shows that the coldest and most arid conditions in the lowland Neotropics during the last glacial occurred during Heinrich stadials. Of all the Heinrich stadials, HS1 was the coldest and driest marking the maximum southward shift of the ITCZ. This interpretation is supported by a marked reduction in precipitation and runoff to the Cariaco Basin (Deplazes et al., 2013), by wet increased rainfall in Brazil inferred from stalagmites and marine sediments (Wang et al., 2004a; Arz et al., 1998), and the $\mathrm{Mg} / \mathrm{Ca}$ SST record from the Orca Basin (Williams et al., 2010). Furthermore, the extreme conditions during HS1 coincide with one of the most extreme drought events of the last $50 \mathrm{ka}$ in Africa (Stager et al., 2011), and the highest $\delta^{18} \mathrm{O}$ values of the Hulu cave stalagmite record indicating a weak monsoon event centered at $16 \mathrm{ka}$ (Wang et al., 2001). Future model studies should consider regional as well as global forcing mechanisms to better explain the large amplitude of temperature change in the terrestrial environment during these events, particularly in the low latitudes.

\section{Conclusion}

We compared three independent methods of glacial temperature reconstruction: pollen-based temperature estimates, tandem measurements of $\delta^{18} \mathrm{O}$ in biogenic carbonate and gypsum hydration water, and clumped isotope thermometry. The combination of temperature estimates from pollen MAT and isotope geochemical methods provide a continuous record of tropical temperature change in 
lowland Central America over the past $42 \mathrm{ka}$. The agreement of the tandem gypsum hydrationcarbonate and clumped isotope methods for the last glacial period provides confidence in the absolute temperature estimates. The results show that temperature decline in the lowland Neotropics was much greater during HSs than previously assumed $\left(6-10^{\circ} \mathrm{C}\right)$. In particular, we record the coldest and driest conditions of the last glacial during HS1. The observed temperatures are considerably colder than inferred from adjacent marine records, highlighting a large land-sea discrepancy in temperature during HSs. Although models correctly predict the sign of temperature and precipitation changes in the Neotropics, they consistently underestimate the degree of cooling observed over land.

\section{Acknowledgements}

We thank J. Rolfe, I. Mather, J. Curtis and F. Gázquez for technical assistance. Authors are grateful to all individuals who participated in the field and laboratory work of the Lake Petén Itzá Scientific Drilling Project. We thank J. Chiang for the fruitful discussion on an earlier stage of the manuscript. This project was financially supported by the SNF (Swiss National Science Foundation Projects PBEZP2 140154 and 200021_143485), the Isaac Newton Trust (Trinity College, University of Cambridge), NERC Grant NE/M003752/1, and the European Research Council under the European Union's Seventh Framework Programme (FP/2007-2013)/ERC Grant Agreement n. 339694 (Water Isotopes of Hydrated Minerals) to D.A. Hodell. We also thank three anonymous reviewers and the handling editor for the constructive and helpful comments.

\section{References}

Anderson, T.F., Arthur, M.A., 1983. Stable isotope of oxygen and carbon and their application to sedimentologic and paleoenvironmental problems. In: Stable Isotopes in Sedimentary Geology, Short Course Notes (ed. Arthur, M.A.). Society Economic Petroleum Mineralogists, pp. 1-151.

Arbuszewski, J., demenocal, P., Kaplan, A., Farmer, E.C., 2010. On the fidelity of shell-derived $\delta^{18} \mathrm{O}_{\text {seawater }}$ estimates. Earth Plan. Sci. Let. 300, 185-196.

Bard, E., Rostek, F., Turon, J-L., Gendreau, S., 2000. Hydrological Impact of Heinrich Events in the Subtropical Northeast Atlantic. Science 289, 1321-1324.

Bernasconi S. M., Hu, B., Wacker, U., Fiebig, J., Breitenbach, S. F. M., Rutz, T., 2013. Background effects on Faraday collectors in gas-source mass spectrometry and implications for clumped isotope measurements. Rapid Comm. Mass Spectrom. 27, 603-612. 
Bush, M.B., Correa-Metrio, A.Y., Hodell, D.A., Brenner, M., Anselmetti, F.S., Ariztegui, D., Mueller, A.D., Curtis, J.H., Grzesik, D.A., Burton, C., Gilli, A., 2009. Re-evaluation of Climate Change in Lowland Central America during the Last Glacial Maximum Using New Sediment Cores form Lake Petén Itzá, Guatemala. In: Past Climate Variability in South America and Sourrounding Regions, Developments in Paleoenvironmental Research 14 (ed. Vimeux, F. et al.). Springer Science + Business Media B.V., pp. 113-128.

Chiang, J.C.H., 2009. The Tropics in Paleoclimate. Ann. Rev. Earth and Planet. Sci., 263-297.

Chiang, J.C.H., Friedman, A.R, 2012. Extratropical cooling, Interhemispheric Thermal Gradients, and Tropical Climate Change. Annu. Rev. Earth Planet. Sci. 40, 383-412.

Clement, A.C., Peterson, L.C., 2008. Mechanisms of abrupt Climate Change of the Last Glacial Period. Rev. of Geophys. 46.

Colinvaux, P.A., Liu, K.-B., de Oliveira, P., Bush, M.B., Miller, M.C., Steinitz Kannan, M., 1996. Temperature Depression in the Lowland Tropics in the Glacial times. Climate Change 32, 19-33.

Correa-Metrio, A., Bush, M.B., Cabrera, K.R., Sully, S., Brenner, M., Hodell, D.A., Escobar, J., Guilderson, T., 2012. Rapid climate change and no-analog vegetation in lowland Central America during the last 86,000 years. Quat. Sci. Rev. 38, 63-75.

Covich, A., 1976. Recent Changes in Molluscan Species Diversity of a Large Tropical Lake (Lago de Peten, Guatemala). Limnology and Oceanography 21(1), 51-59.

Dennis, K.J., Affek, H.P., Passey, B.H., Schrag, D.P., Eiler, J.M., 2011. Defining an absolute reference frame for 'clumped' isotope studies of $\mathrm{CO}_{2}$. Geochim. Cosmochim. Act. 75, 7117-7131.

Deplazes, G., Lückge, A., Peterson, L.C., Timmermann, A., Hamann, Y., Hughen, K.A., Röhl, U., Laj, C., Cane, M.A., Sigman, D.M., Haug, G.H., 2013. Links between tropical rainfall and North Atlantic climate during the last glacial period. Nature Geoscience 6, 213-217.

Dunning, N., Rue, D.J., Beach, T., Covich, A., Traverse, A., 1998. Human-Environment Interactions in Tropical Watershed: The Paleoecology of Laguna Tamarindito, El Péten, Guatemala. Journal of Field Archaeology 25(2), 139-151. 
Eiler, J. M., Schauble, E., 2004. ${ }^{18} \mathrm{O}^{13} \mathrm{C}^{16} \mathrm{O}$ in Earth's atmosphere. Geochim. Cosmochim. Act. 68(23), $4767-4777$.

Eiler, J.M., 2007. "Clumped-isotope" geochemistry - The study of naturally-occurring multiplysubstituted isotopologues. Earth Plan. Sci. Lett. 262, 309-327.

Escobar, J., Hodell, D.A., Brenner, M., Curtis, J.H., Gilli, A., Mueller, A.D., Anselmetti, F.S., Ariztegui, D., Grzesik, D.A., Pérez, L., Schwalb, A., Guilderson, T.P., 2012. A 43-ka record of paleoenvironmental change in the Central American lowlands inferred from stable isotopes of lacustrine ostracods. Quat. Sci. Rev. 37, 92-104.

Fernandez, A., Tang, J., Rosenheim, B.E., 2014. Siderite 'clumped` isotope thermometry: A new paleoclimate proxy for humid continental environments. Geochim. Cosmochim. Act. 126, 411-421.

Folkins, I., Braun, C., 2003. Tropical Rainfall and Boundary Layer Moist Entropy. J. Clim. 16, 18071820.

Fontes, J.C., Gonfiantini, R., 1967. Fractionnement isotopique dans l'eau de crystallization du sulfate de calcium. Geol. Rundsch. 55, 172.

Gázquez, F., Mather, I., Rolfe, J., Evans, N.P., Herwartz, D., Staubwasser, M., Hodell, D.A., 2015. Simultaneous analysis of ${ }^{17} \mathrm{O} /{ }^{16} \mathrm{O},{ }^{18} \mathrm{O} /{ }^{16} \mathrm{O}$ and ${ }^{2} \mathrm{H} /{ }^{1} \mathrm{H}$ of gypsum hydration water by cavity ringdown laser spectroscopy. R. Comm. Mass. Spec. 29, 1-10.

Ghosh, P., Adkins, J., Affek, H., Balta, B., Guo, W., Schauble, E.A., Schrag, D., Eiler, J.M, 2006. ${ }^{13} \mathrm{C}-{ }^{18} \mathrm{O}$ bonds in carbonate minerals: A new kind of paleothermometer. Geochim. Cosmochim. Act. 70, 1439-1456.

Gonfiantini,R., Fontes, J.C., 1963. Oxygen isotope fractionation in the water of crystallization of gypsum. Nature 200, 644-646.

Grauel, A.L., Schmid, T.W., Hu, B., Bergami, C., Capotondi, L., Zhou, L., Bernasconi, S.M., 2013. Calibration and application of the 'clumped isotope' thermometer to foraminifera for high-resolution climate reconstructions. Geochim. Cosmochim. Act. 108, 125-140.

Grossmann, R., Ku, T., 1986. Oxygen and carbon fractionation in biogenic aragonite: temperature effect. Chem. Geol. 59, 59-74. 
Henkes, G. A., Passey, B. H., Wanamaker Jr., A. D., Grossman, E. L., Ambrose Jr., W. G., Caroll, M. L., 2013. Carbonate clumped isotope compositions of modern marine mollusk and brachiopod shells. Geochim. Cosmochim. Act. 106, 307-325.

Hill, H.W., Flower, B.P., Quinn, T.M., Hollander,D.J., Guilderson, T.P., 2006. Laurentide Ice Sheet meltwater and abrupt climate change during the last glaciation. Paleocean. 21.

Hillesheim, M.B., Hodell, D.A., Leyden, B.W., Brenner, M., Curtis, J.H., Anselmetti, F.S., Ariztegui, D., Buck, D.G, Guilderson, T.P., Rosenmeier, M.F., Schnurrenberger, D.W., 2005. Climate change in lowland Central America during the late deglacial and early Holocene. J. Quartern. Science 20(4), 363-376.

Hodell, D., Anselmetti,F., Brenner, M., Ariztegui, D., PISDP Scientific Party, 2006. The Lake Petén Itzá Scientific Drilling Project. Scientific Drilling 3, 25-29.

Hodell, D.A., Anselmetti, F.S., Ariztegui, D., Brenner, M., Curtis, J.H., Gilli, A., Grzesik, D.A., Guilderson, T.J., Müller, A.D., Bush, M.B., Correa-Metrio, A., Escobar, J., Kutterolf, S., 2008. An 85-ka record of climate change in lowland Central America. Quat. Sci. Rev. 27, 1152-1165.

Hodell, D.A., Turchyn, A.V., Wiseman, C.J., Escobar, J., Curtis, J.H., Brenner, M., Gilli, A., Mueller, A.D., Anselmetti, F., Ariztegui, D., Brown, E.T., 2012. Late Glacial temperature and precipitation changes in the lowland Neotropics by tandem measurements of $\delta^{18} \mathrm{O}$ in biogenic carbonate and gypsum hydration water. Geochim. Cosmochim. Act. 77, 352-368.

Huntington, K.W., Eiler, J.M., Affek, A.P., Guo, W., Bonifacie, M., Yeung, L.Y., Thiagarajan, N., Passey,B., Tripati, A., Daëron, M., Came, R., 2009. Methods and limitations of 'clumped' $\mathrm{CO}_{2}$ isotope $\left(\triangle_{47}\right)$ analyses by gas-source isotope mass spectrometry. J. Mass. Spec., http://dx.doi.org/10.1002/jms.1614.

Kele, S., Breitenbach, S.F.M., Capezzuoli, E., Meckler, A.N., Ziegler, M., Millan, I.M., Kluge, T., Deák, J., Hanselmann, K., John, C.M., Yan, H., Liu, Z., Bernasconi, S.M., accepted. Temperature dependence of oxygen- and clumped isotope fractionation in carbonates: a study of travertines and tufas in the 6-95 ${ }^{\circ} \mathrm{C}$ temperature range. Geochim. Cosmochim. Act., 168, 172-192 .

Lea D.W., Pak, D.K., Peterson, I.C., Hughen, K.A., 2003. Synchroneity of tropical and high-latitude Atlantic temperatures over the last glacial termination. Science 301, 1361-1364. 
Leyden, B.W., Brenner, M., Hodell, D.A., Curtis, J.H., 1994. Orbital and internal forcing of climate on the Yucatan Peninsula for the past ca. 36 ka. Palaeogeogr., Palaeoclim., Palaeoecol. 109, 193210.

Martrat, B., Grimalt, J.O., Shackleton, N.J., de Adreu, L., Hutterli, M.A., Stocker, F., 2007. Four climate cycles of recurring deep and surface water destabilizations on the Iberian Margin. Science 317, 502-507.

Martrat, B., Jimenez-Amal, P., Zahn, R., Grimalt, J.O., 2014. Similarities and dissimilarities between the last two glaciations and interglaciations in the north Atlantic region. Quat. Sci. Rev. 99, 122-134.

Meckler, A.N., Ziegler, M., Millan, M.I., Breitenbach, S.F.M., Bernasconi, S.M., 2014. Long-term performance of the Kiel carbonate device with a new correction scheme for clumped isotope measurements. R. Comm. Mass. Spec. 28, 1705-1715.

Menviel, L., Timmermann, A., Friedrich, T., England, M.H., 2014. Hindcasting the continuum of Dansgaard-Oeschger variability: mechanisms, patterns and timing. Clim. Past 10, 63-77.

Mueller, A.D., Anselmetti, F.S., Aritzegui, D., Brenner, M., Curtis, J.H., Escobar, J., Gilli, A., Grzesk, D.A., Hodell, D.A., Guilderson, T.J., Kutterolf, S., Ploetze, M.L., 2010. Late Quaternary palaeoenvironment of Lake Petén Itzá, northern Guatemala: evidence from deep drill holes and seismic stratigraphy. Sedimentology 57, 1220-1245.

Pérez, L, Lorenschat, J., Brenner, M., Scharf, B., Schwalb, A., 2010. Extant freshwater ostracodes (Crustacea: Ostracoda) from Lago Petén Itzá, Guatemala. Rev. Biol. Trop. 58(3), 871-895.

Peterson, L. C., Haug, G.H., Hughen, K.A., Röhl, U., 2000. Rapid Changes in the Hydrologic Cycle of the Tropical Atlantic During the Last Glacial. Science 290, 1947-1951.

Rind, D., Peteet, D., 1985. Terrestrial conditions at the last Glacial Maximum and CLIMAP SeaSurface Temperature estimates: Are they consistent? Quat. Res. 24, 1-22.

Roy, A.J., Lachniet, M.S., 2010. Late Quaternary glaciation and equilibrium-line altitudes of the Mayan Ice Cap, Guatemala, Central America. Quat. Res. 74, 1-7. 
Schauble, E. A., Ghosh P., Eiler J. M., 2006. Preferential formation of 13C-18O bonds in carbonate minerals, estimated using first-principle lattice dynamics. Geochim. Cosmochim. Act. 70, 2510-2529.

Schmid, T.W., Bernasconi, S.M., 2010. An automated method for ,clumped isotope“ measurements on small carbonate samples. R. Comm. Mass. Spec. 24, 1955-1963.

Schmid, T.W., Radke, J., Bernasconi, S.M., 2012. Clumped-Isotope Measurements on Small Carbonate Samples with a Kiel IV Carbonate Device and a MAT 253 Mass Spectrometer. Thermo Fisher Application Note $\mathbf{3 0 2 3 3}$.

Schmidt, M.W., Spero, H.J., Lea, D.W., 2004. Links between salinity variation in the Caribbean and North Atlantic thermohaline circulation. Nature 428, 160-163.

Schneider von Deimling, T., Ganopolski, A., Held, H., Rahmstorf, S., 2006. How cold was the Last Glacial Maximum? Geophys. Res. Lett. 33.

Seager, R., Clement, A.C., Cane, M.A., 2000. Glacial Cooling in the Tropics: Exploring the roles of the Tropospheric Water Vapor, Surface Wind Speed, and Boundary Layer Processes. J. Atm. Sci. 57, 2144-2157.

Shanahan, T.M., Pigati, J.S., Dettman, D.L., Quade, J., 2005. Isotopic variability in the aragonite shells of freshwater gastropods living in springs with nearly constant temperature and isotopic composition. Geochim. Cosmochim. Act. 69(16), 3946-3966.

Stager, J.C., Ryves, D.B., Chase, B.M., Pausata, F.S.R., 2011. Catastrophic Drought in the Afro-Asian Monsoon Region During Heinrich Event 1. Science 331, 1299-1302.

Wang, C., Enfield, D.B., 2001. The tropical Western Hemisphere Warm pool. Geophys. Res. let. 28, 1635-1638.

Wang, Y.J., Cheng, H., Edwards, R.L., An, Z.S., Wu, J.Y., Shen, C-C., Dorale, J.A., 2001. A HighResolution Absolute-Dated Late Pleistocene Monsoon Record from Hulu Cave, China. Science 294, 2345-2348.

Wang, X., Auler, A.S., Edwards, R.L., Cheng, H., Cristalli, P.S., Smart P.L., Richards, D.A., Shen, CC., 2004a. Wet periods in northeastern Brazil over the past $210 \mathrm{kyr}$ linked to distant climate anomalies. Nature 432, 740-743. 
Wang Z., Schauble E. A., Eiler J. M., 2004b. Equilibrium thermodynamics of multiply substituted isotopologues of molecular gases. Geochim. Cosmochim. Act. 68(23), 4779-4797.

Williams, C., Flower, B.P., Hastings, D.W., Guilderson, T.P., Quinn, K.A., Goddard, E.A., 2010. Deglacial abrupt climate change in the Atlantic Warm Pool: A Gulf of Mexico perspective. Paleocean. 25.

Zaarur, S., Affek, H.P., Brandon, M.T., 2013. A revised calibration of the clumped isotope thermometer. Earth Plan. Sci. Lett. 382, 47-57. 


\section{Figure captions}

Figure 1: Map of the Intra American Seas showing the location of the Petén Lake District in northern Guatemala (after Bush et al., 2009). Stars indicate the position of cores from the Orca Basin (Gulf of Mexico) and Cariaco Basin (Caribbean) discussed in the text.

Figure 2: Modern hydrographic profiles of Lake Péten Itzá: A) summer (red) and winter (blue, black) temperature; B) $\delta^{18} \mathrm{O}$ and C) $\delta \mathrm{D}$ of lake water collected in August 2002 (Hodell et al., 2012, modified).

Figure 3: Results of core PI-6 from Lake Petén Itzá. A) Temperatures derived using $\delta^{18} \mathrm{O}$ of ostracod shells and gypsum hydration water (black diamonds); Temperatures derived using $\delta^{18} \mathrm{O}$ of gastropod shells and gypsum hydration water (blue triangles); $\Delta_{47}$-temperatures (purple squares), and pollenbased temperature estimates using MAT (green; Correa-Metrio et al., 2012). B) $\delta^{18} \mathrm{O}$ of lake water estimated by measurement of gypsum hydration water (blue diamonds), and calculated using $\Delta_{47^{-}}$ temperatures and $\delta^{18} \mathrm{O}$ of gastropods (light blue squares). C) $\delta \mathrm{D}$ of lake water from gypsum hydration water. D) $d$-excess. E) $\delta^{18} \mathrm{O}$ of ostracod shells (black and grey crosses; Escobar et al., 2012) and $\delta^{18} \mathrm{O}$ of gastropod shells (blue triangles) . F) Magnetic susceptibility (low magnetic susceptibility indicates gypsum beds, and higher clay; Hodell et al., 2008). Light grey boxes mark the Heinrich Stadials (HSs).

Figure 4: a) Comparison of $\Delta_{47}$-temperatures of gastropods and temperatures derived using $\delta^{18} \mathrm{O}$ of ostracod shells and gypsum hydration water of HSs over the past $42 \mathrm{ka}$ (black squares), and $4_{47^{-}}$ temperatures of gastropods and temperatures derived using $\delta^{18} \mathrm{O}$ of gastropod shells and gypsum hydration water of HSs over the past 42ka (red squares). b) Comparison of $\delta^{18} \mathrm{O}$ of gypsum hydration water, and values calculated using $\Delta_{47}$-temperatures and $\delta^{18} \mathrm{O}$ of gastropods of HSs over the past $42 \mathrm{ka}$. The error bars represent the standard deviation of the gypsum hydration values and the $\Delta_{47}$-values over a certain time interval (see Table 2).

Figure 5: Comparison of marine and terrestrial temperature proxies: $\mathrm{Mg} / \mathrm{Ca}$-temperatures of G. ruber (white) at Site VM28-122 in the Caribbean Sea, grey (Schmidt et al., 2004); Mg/Ca-temperatures of G. ruber (white) in Cariaco Basin, Site PL07-39PC, red (Lea et al., 2003); Mg/Ca-temperatures of G. ruber (pink) in cores MD02-2550 and MD02-2551 from the Orca Basin, Gulf of Mexico, light blue (Williams et al., 2010; Hill et al., 2006); Average temperatures derived using $\delta^{18} \mathrm{O}$ of ostracod shells and gypsum hydration water (black squares); average temperatures derived using $\delta^{l 8} \mathrm{O}$ of gastropod shells and gypsum hydration water (blue triangles); $\Delta_{47}$-temperatures (purple squares), and pollenbased temperature estimates using MAT, green line (Correa-Metrio et al., 2012) in Lake Petén Itzá 
Core PI-6. The error bars represent the standard deviation of the gypsum hydration values and the $\Delta_{47}-$ values over a certain time interval (see Tab. 1). Light grey boxes mark Heinrich Stadials (HSs). The grey scattered line indicates the modern seasonal epilimnetic temperature range of Lake Petén Itzá.

Figure 6: Comparison of paleotemperatures of Lake Petén Itzá core PI-06 with core MD01-2444 from the Iberian Margin (Martrat et al., 2007). Core PI-06: Average temperatures derived using $\delta^{18} \mathrm{O}$ of ostracod shells and gypsum hydration water (black squares); average temperatures derived using $\delta^{l 8} \mathrm{O}$ of gastropod shells and gypsum hydration water (blue triangles); $\Delta_{47}$-temperatures (purple squares), and pollen-based temperature estimates using MAT, green line (Correa-Metrio et al., 2012). Core MD01-2444: $\mathrm{U}^{\mathrm{k}}{ }^{37}$-temperatures (blue line); $\mathrm{C}_{37: 4}$ alkenones, black line (Martrat et al., 2007). Light grey boxes mark Stadials. 


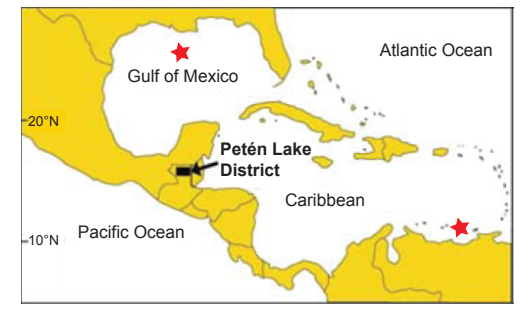




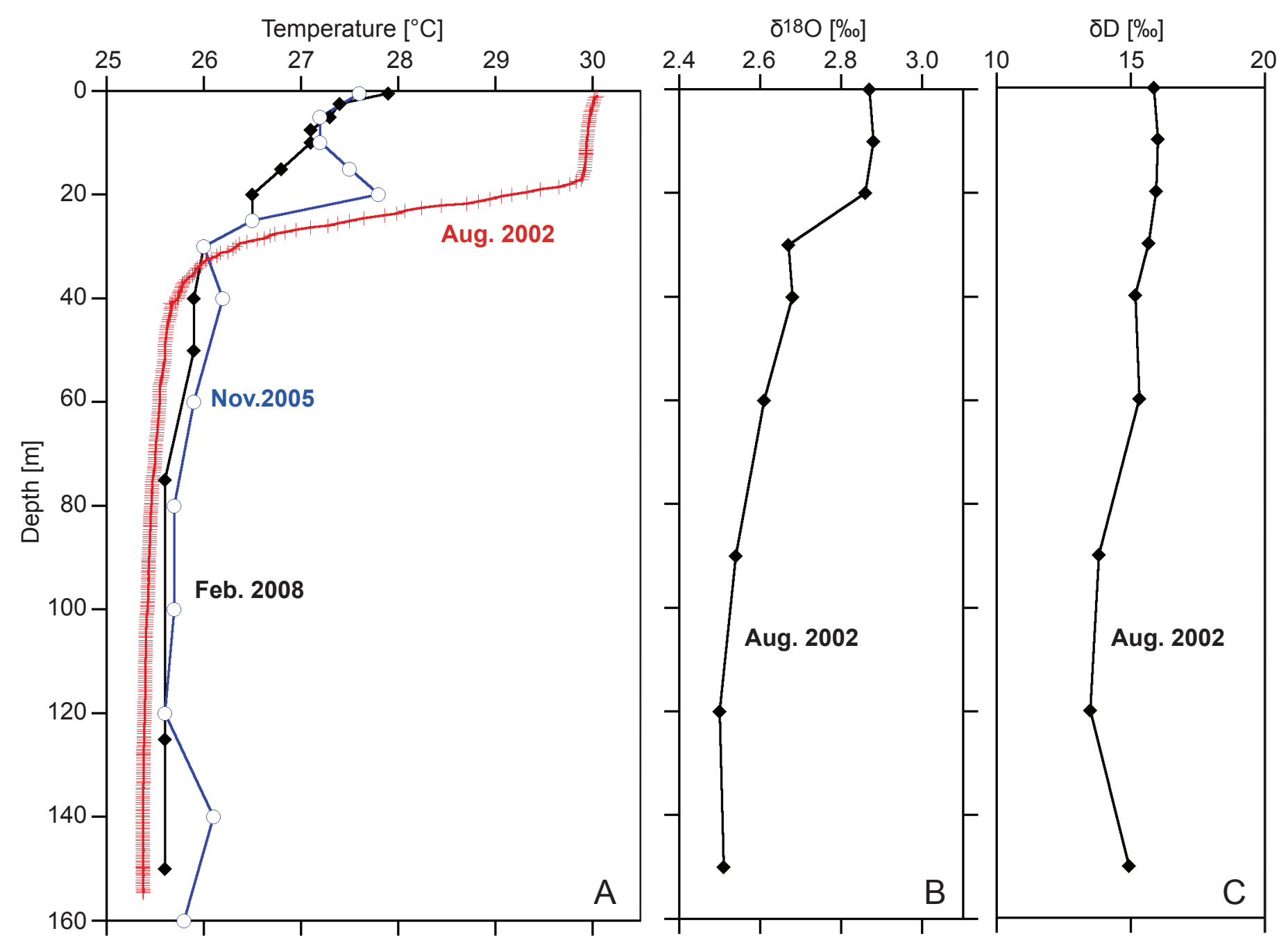




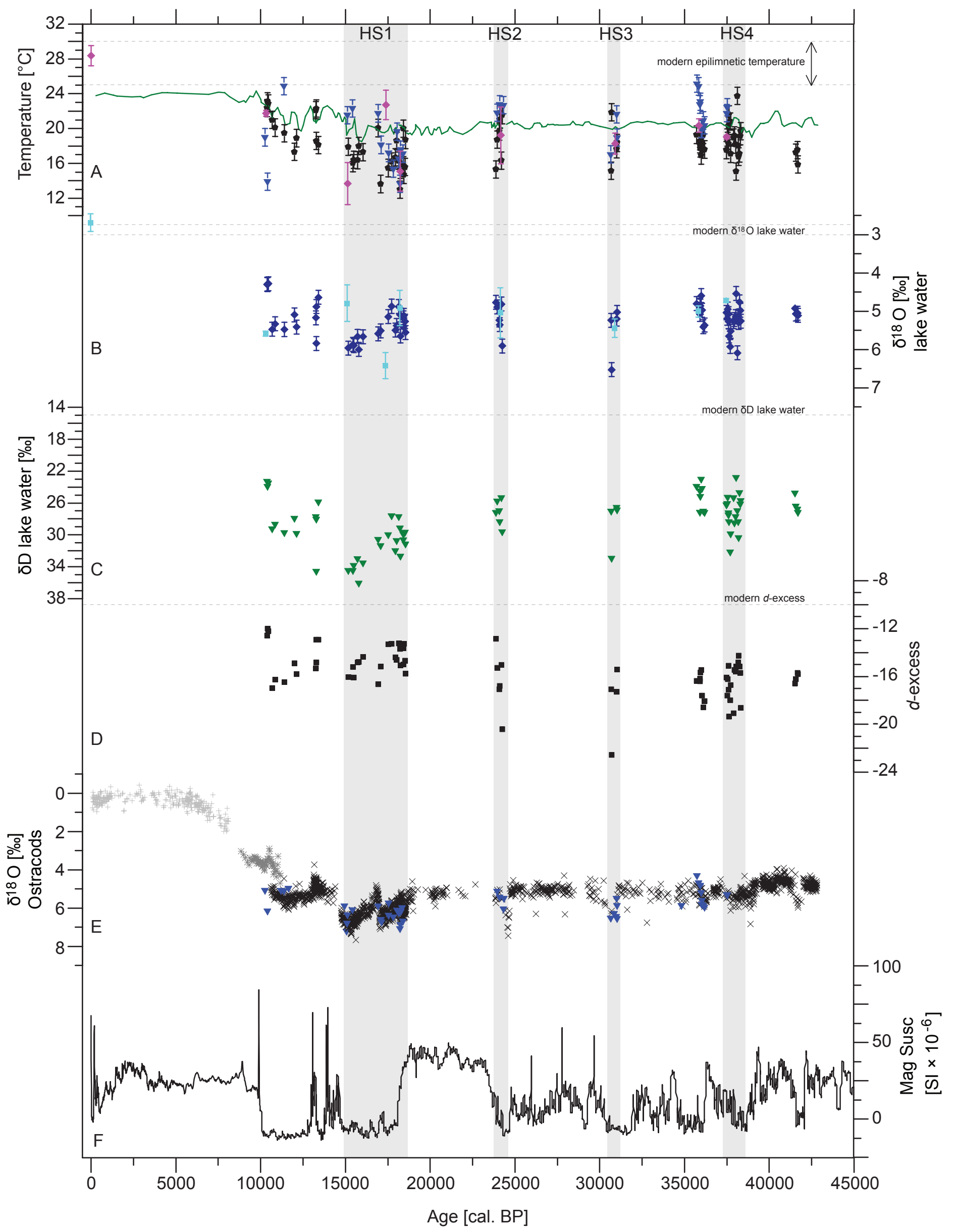



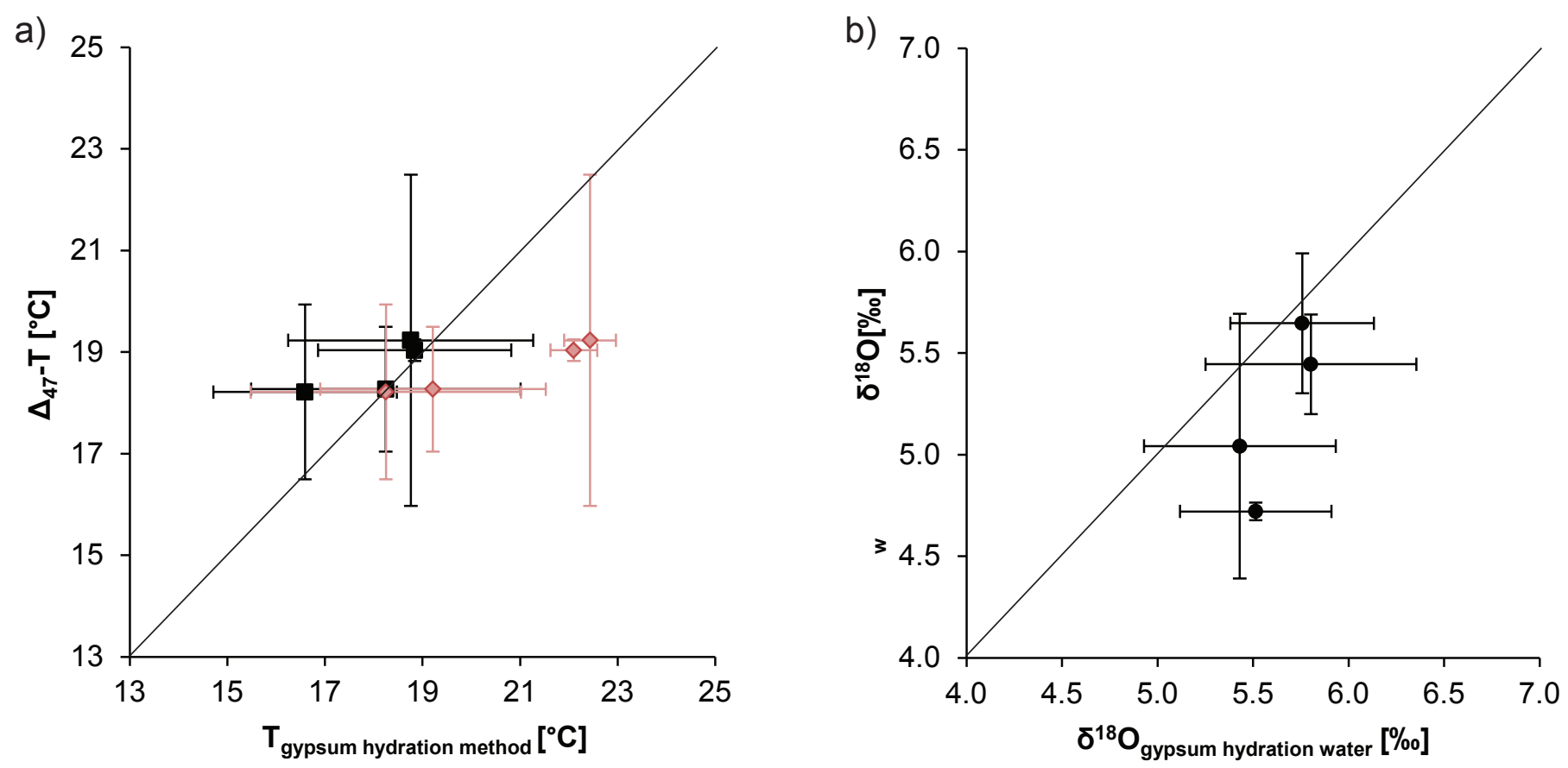


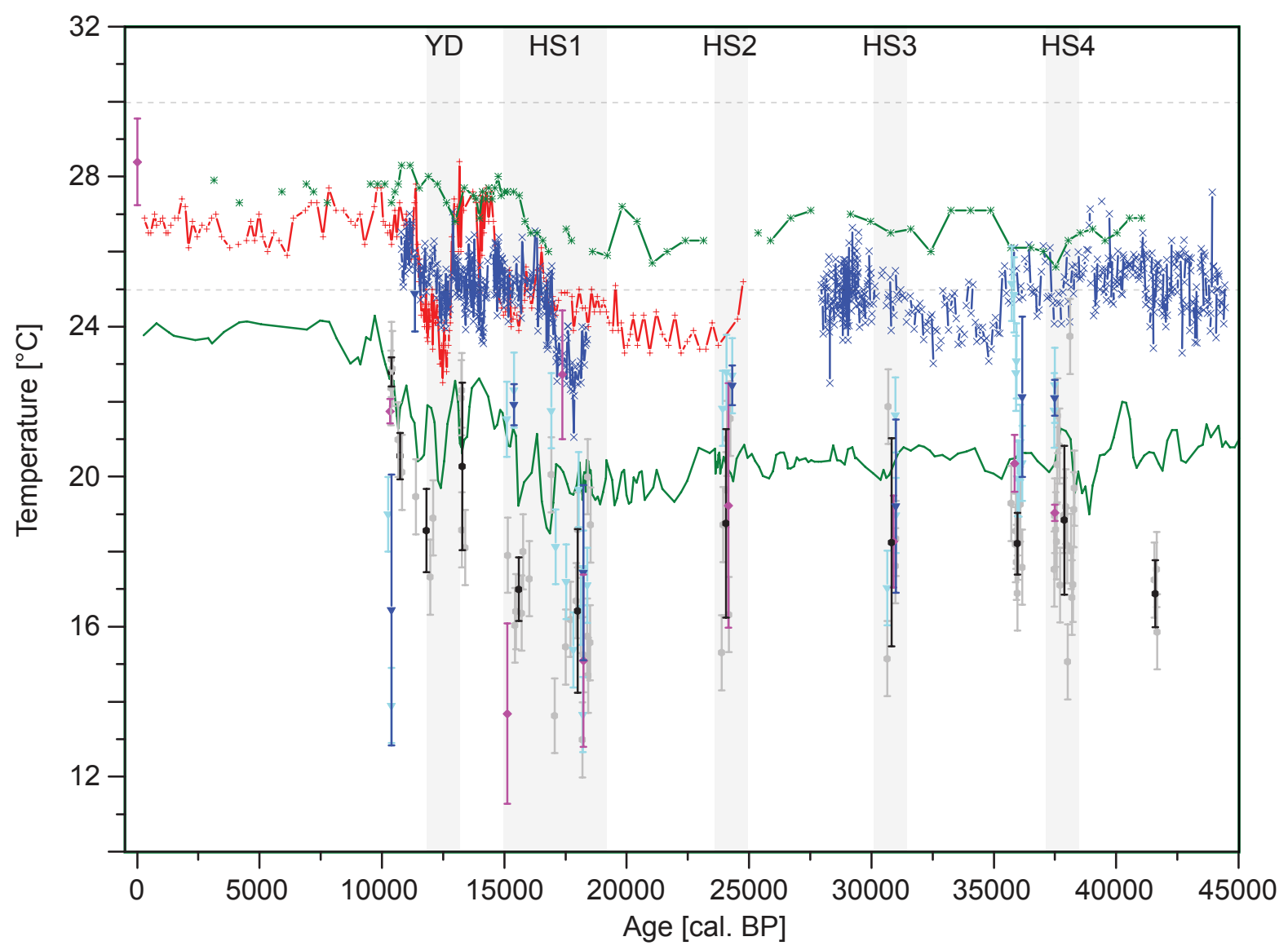




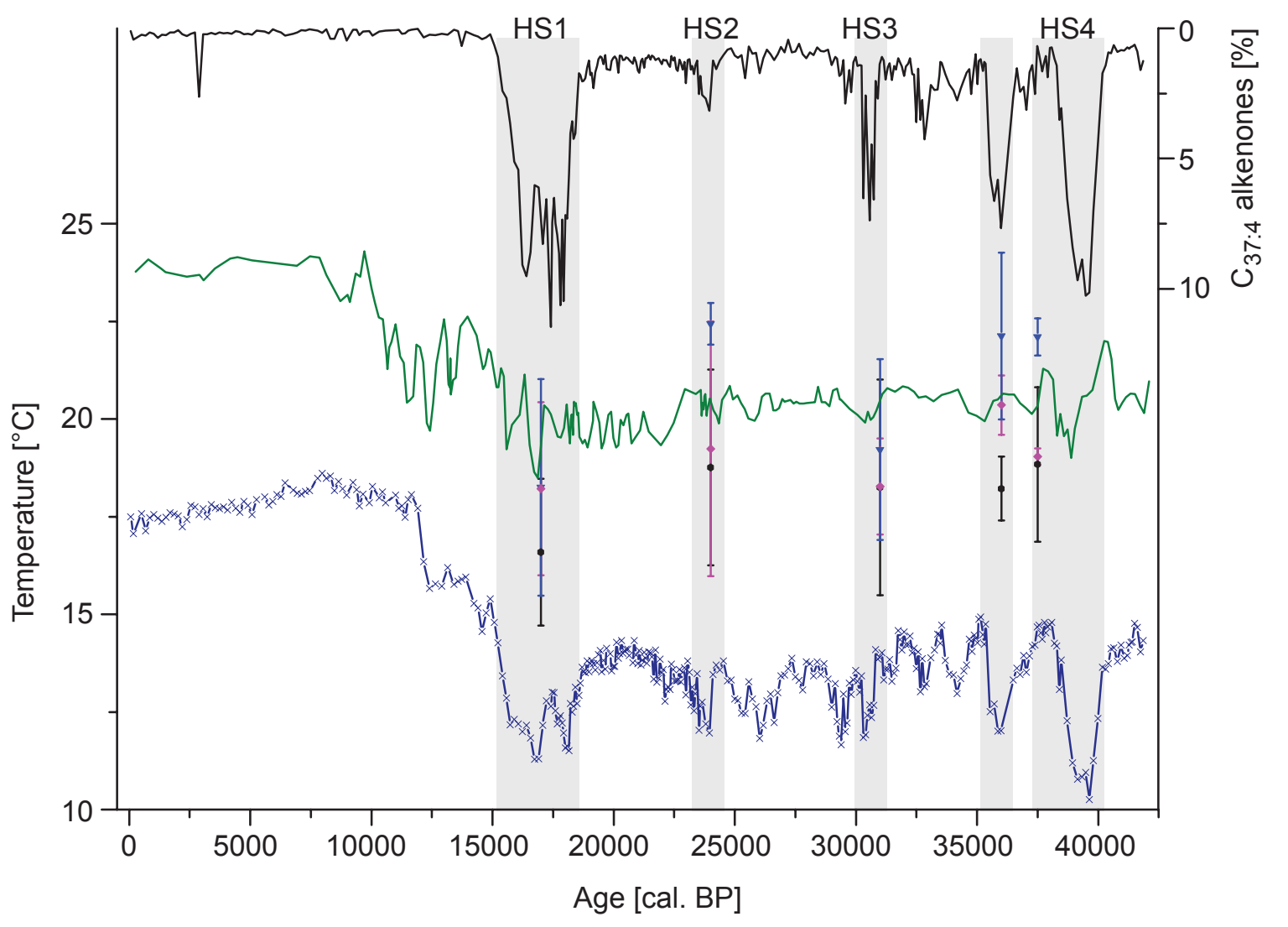




\begin{tabular}{|c|c|c|c|c|c|c|c|c|c|c|c|c|}
\hline \multirow[b]{2}{*}{ Sample } & \multicolumn{6}{|c|}{ Godwin Laboratory } & \multicolumn{6}{|l|}{ ETH Zurich } \\
\hline & $\begin{array}{l}\delta^{13} \mathrm{C} \\
{[\% \circ, \text { VPDB] }}\end{array}$ & STDEV & $\begin{array}{l}\delta^{18} \mathrm{O} \\
{[\% \circ, \text { VPDB] }}\end{array}$ & STDEV & $\begin{array}{c}\Delta_{47 \text { ARF }} \\
{[\% \text { [\% }}\end{array}$ & SE & $\begin{array}{l}\delta^{13} \mathrm{C} \\
{[\% \circ, \text { VPDB] }}\end{array}$ & STDEV & $\begin{array}{l}\delta^{18} 0 \\
{[\%, \text { VPDB] }}\end{array}$ & STDEV & $\begin{array}{l}\Delta_{47 \text { ARF }} \\
{[\% \text { \% }}\end{array}$ & SE \\
\hline \multicolumn{13}{|l|}{ Carbonate Standards } \\
\hline Iso-A & 2.06 & 0.01 & -2.22 & 0.03 & 0.267 & 0.008 & 2.14 & 0.03 & -2.18 & 0.06 & 0.267 & 0.003 \\
\hline Iso-B & -10.08 & 0.01 & -18.62 & 0.03 & 0.248 & 0.009 & -10.1 & 0.03 & -18.76 & 0.09 & 0.269 & 0.004 \\
\hline Iso-R & 1.74 & 0.03 & -1.8 & 0.04 & 0.501 & 0.010 & 1.81 & 0.03 & -1.77 & 0.06 & 0.524 & 0.004 \\
\hline Iso-C & -10.18 & 0.01 & -18.81 & 0.03 & 0.723 & 0.008 & -10.11 & 0.03 & -18.82 & 0.09 & 0.705 & 0.004 \\
\hline CarraraZ & 2.21 & 0.01 & -1.27 & 0.03 & 0.379 & 0.006 & & & & & & \\
\hline \multicolumn{13}{|l|}{ Biogenic carbonates } \\
\hline Eggshell of an ostrich & -12.64 & 0.07 & -3.91 & 0.03 & 0.628 & 0.009 & -12.68 & 0.02 & -3.84 & & 0.648 & 0.014 \\
\hline Dyscolia wyvillei & 2.38 & 0.04 & 2.28 & 0.05 & 0.715 & 0.002 & 2.51 & 0.01 & 2.47 & & 0.742 & 0.018 \\
\hline
\end{tabular}

Tab. 1: Isotopic composition of the five carbonate standards used for the correction scheme (mean, standard deviation (STDEV) and standard error (SE)) and the isotopic composition of two biogenic carbonates reported by Kele et al. (2015). The left part of the table shows the values from ETH Zurich (Meckler et al., 2014 and Kele et al., 2015). 


\begin{tabular}{|c|c|c|c|c|c|}
\hline & $\begin{array}{l}\text { Gypsum T } \\
\text { ostracod }\left[{ }^{\circ} \mathrm{C}\right]\end{array}$ & $\begin{array}{l}\text { Gypsum } \mathbf{T} \\
\text { gastropod }\left[{ }^{\circ} \mathrm{C}\right]\end{array}$ & $\Delta_{47}-\mathrm{T}\left[{ }^{\circ} \mathrm{C}\right]$ & $\begin{array}{l}\delta^{18} \mathrm{O} \text { hydration } \\
\text { water [\%] }\end{array}$ & $\begin{array}{l}\delta^{18} \mathrm{O}_{\mathrm{w}} \text { clumped } \\
\text { isotopes [\%] }\end{array}$ \\
\hline HS1 & $16.6 \pm 1.9$ & $18.3 \pm 2.8$ & $18.2 \pm 1.7$ & $5.8 \pm 0.4$ & $5.6 \pm 0.3$ \\
\hline HS2 & $18.8 \pm 2.5$ & $22.4 \pm 0.5$ & $19.2 \pm 3.3$ & $5.4 \pm 0.5$ & $5.0 \pm 0.7$ \\
\hline HS3 & $18.2 \pm 2.8$ & $19.2 \pm 2.3$ & $18.3 \pm 1.2$ & $5.8 \pm 0.6$ & $5.4 \pm 0.2$ \\
\hline HS4 & $18.8 \pm 2.0$ & $22.1 \pm 0.5$ & $19.0 \pm 0.2$ & $5.5 \pm 0.4$ & $4.7 \pm 0.1$ \\
\hline
\end{tabular}

Tab. 2: Average temperatures and lake water $\delta^{18} \mathrm{O}$ during Heinrich Stadials (HSs) using tandem measurements of gypsum hydration water and ostracod and gastropod shells, respectively, and $\Delta_{47}$-temperatures and $\delta^{18} \mathrm{O}$ of gastropod shells. All values are reported together with their standard deviation over each HS. 